\title{
Prevention Models of Occupational Contact Dermatitis in Beauty Salon Employees of Kendari City
}

Nurhidayah Mosa Saeni ${ }^{1}$, Furqan Naiem ${ }^{1}$, Sukri Paluturi ${ }^{2}$, Yahya Thamrin ${ }^{1}$, Syamsiar S. Russeng ${ }^{1}$, Ridwan Amiruddin ${ }^{3}$

${ }^{1}$ Department of Occupational Safety and Health, Faculty of Public Health, Hasanuddin University, Indonesia

${ }^{2}$ Dapartment of Policy Administration and Health, Faculty of Public Health, Hasanuddin University, Indonesia

${ }^{3}$ Department of Epidemiology, Faculty of Public Health, Hasanuddin University, Indonesia

Received: October 30, $2020 \quad$ Revised: November 12, $2020 \quad$ Accepted: November 22, 2020

\begin{abstract}
This study aims to determine the effect of modifying factors, perceived vulnerability, perceived seriousness, perceived barriers and encouragement to prevent occupational contact dermatitis on beauty salon employees in Kendari City. This research is a quantitative study with a crosssectional study approach using an explanative survey research design with a sample size of 100 respondents. The sampling technique used purposive random sampling. The data was collected by means of a questionnaire. Data analysis in this study used the SPSS program and Partial Least Squares (PLS). The results of this study indicate that there is a significant influence between modifying factors on perceptions of seriousness and barriers, on perceptions of vulnerability, there is a significant influence between perceptions of vulnerability, seriousness, barriers, encouragement on the prevention of occupational contact dermatitis.
\end{abstract}

Keywords: Modifying Factors, Encouragement, Perceived Seriousness, Perceived Inhibition

\section{Introduction}

Industrial development that occurs in several developing countries occurs very rapidly with the establishment of various companies and workplaces. This is accompanied by a greater and more varied risk of danger due to technology transfer where the use of increasingly complex work machines and equipment to support work processes, causing health problems for workers (International Labour Organization, 2018; Kuhn et al., 2018). Of all occupational diseases occupational dermatitis occupies the highest position with a percentage of around 50-60\%, therefore this disease should receive proportional attention. Occupational dermatitis is a disorder caused by work and/or work environment. Another term for occupational dermatitis is a skin disease that occurs as a result of an employment relationship. The disease occurs when the worker is doing work or is caused by factors in the work environment (Suma'mur, 2014).

In North Bavaria, hairdressing is the occupation that experiences skin diseases due to occupational contact dermatitis with the highest incidence rate of 67.2/10,000 workers for allergic contact dermatitis and 46.9/10,000 workers for irritant contact dermatitis. Then followed by bakers with an incidence rate of 10.9/10,000 workers for allergic contact dermatitis and 23.5 / 10,000 workers for irritant contact dermatitis (Eeckelaert et al., 2014). 
The incidence of dermatitis in Indonesia in 2009 was found as many as $92.5 \%$ of cases and in 2013 when there was a meeting of specialist doctors it was reported that $90 \%$ of occupational skin diseases were contact dermatitis, both Irritant Contact Dermatitis (DKI) or Allergic Contact Dermatitis (DKA). Based on Audina's research, et al (2017) showed that of the 41 respondents, 23 of them experienced occupational contact dermatitis $(56.1 \%)$. The results of statistical analysis showed that the frequency of exposure $(\mathrm{p}=0.037)$ had a significant relationship with the occurrence of occupational contact dermatitis (Audina et al., 2017). The lack of knowledge about personal protection and the impact of this will cause harm when working in salons causing workers to be reluctant or unable to prevent these hazards, where when workers know the dangers of chemicals contained in cosmetics or hair care ingredients used then at least they will use gloves in order to reduce exposure to these chemicals (Ma et al., 2019).

Kendari City is based on a population projection in 2018 of 347,496 people, consisting of 175,337 male residents and 172,159 female residents. Compared to the population projection in 2017, the population of Kendari City experienced a growth of 3.46 percent with the male population growth percentage of 3.52 percent and the female population of 3.39 percent respectively. This increase in population has resulted in an increasing number of unemployed The large number of unemployed people who are inversely proportional to job vacancies forces people to try themselves to make money. Working as an employee of a beauty salon is an alternative that many people choose because they don't need to go to high school and only have skills or study at work. (BPS, 2019).

Beauty salon is a center for body, face, and hair care that is here for women who always want to look beautiful, fresh and radiant all day long in a practical and comfortable way. Salon employees are one of the workers most frequently affected by contact dermatitis. This is due to the large number of chemicals contained in cosmetic products that are often used by salon workers such as make up tools, nail dyes, shampoo, hair dye, hair straighteners, hair curlers, sprays, and hair conditioners (Jason, 2017). This study uses a theory in overcoming the incidence of contact dermatitis among salon workers in Kendari City, namely the theory of Health Believe Models (HBM) combined with the Nordic Occupational Skin Questionnaire-NOSQ-2002. Modifying factors such as age, gender, history of contact dermatitis, knowledge in HBM theory can influence perceptions and coupled with encouragement from within, family, and work environment which are expected to change the behavior of salon employees in taking preventive measures to avoid contact dermatitis.

\section{Methods}

The type of research used in this is quantitative with a cross-sectional study approach using an explanative survey research design that aims to analyze the work-induced contact dermatitis prevention model for beauty salon employees located in Kendari City. The population in this study were all employees of the beauty salon in Kendari City with a total sample of 100 respondents who were taken using the purposive random sampling method, which is based on inclusion criteria. Data collection was carried out through questionnaires and observations. Observations on beauty salon employees in Kendari City were carried out to see the work procedures of beauty salon employees whether to use personal protective equipment (PPE) or not. The data obtained were analyzed using computer applications. Descriptive analysis uses the SPSS application to determine rankings, frequency distribution, while inferential analysis uses the partial least square (PLS) application to see the influence between the independent and dependent variables. 


\section{Results and Discussion}

Researchers measure the existence of a variable using research instruments. After that, continue the analysis to find the influence of the variables with other variables. In this study, there were three variables studied, namely Modifying Factors (X1), Perception of Conventions (X2), Perception of Seriousness (X3), Perception of Barriers (X4), Encouragement (X5), Prevention of Contact Dermatitis (Y). Where there are indicators that will be measured with an ordinal scale.

\section{Designing the Model / Conceptualizing the Model}

Designing a model is the first step in PLS-SEM analysis, consisting of an inner model (structural model) and an outer model (measurement model).

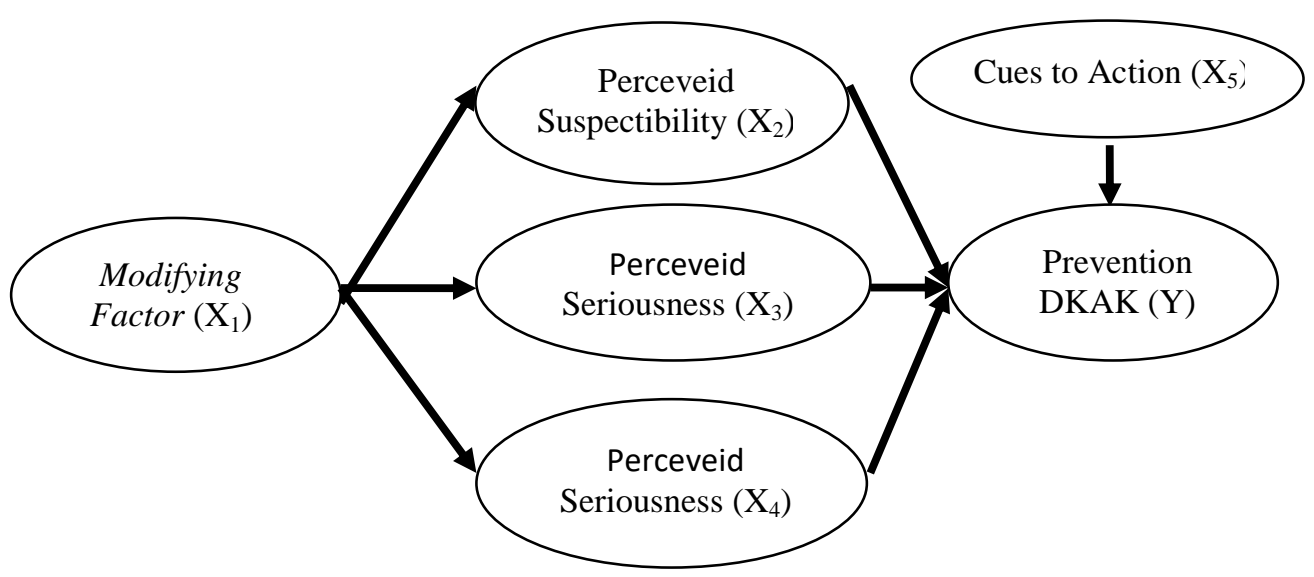

Figure 1. Structural Model

\section{Path diagram construction (Path Diagram)}

The path diagram is used to explain the pattern of relationships between latent variables (constructs) and the relationships between latent variables (constructs) and their indicators. The following is a path diagram that can be seen in Figure 2.

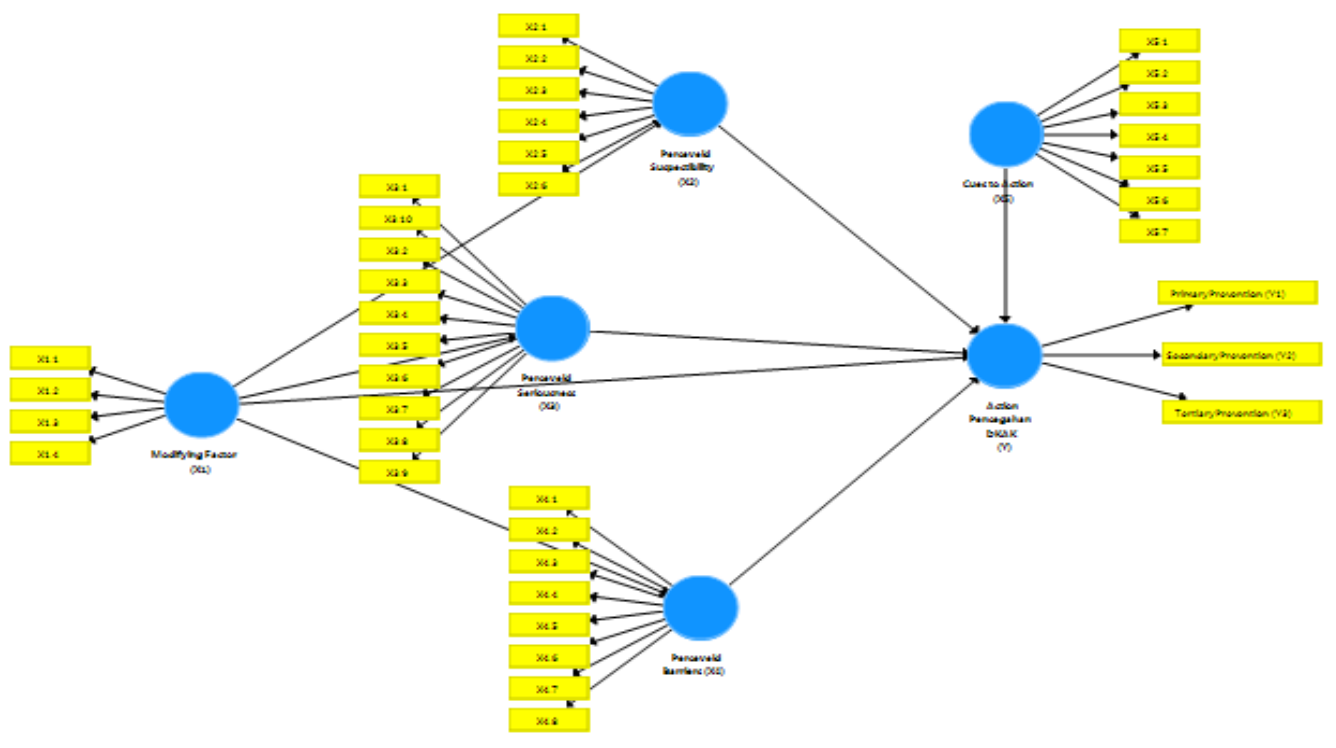

Figure 2. First PLS Model 


\section{Results of the Analysis}

Partial Least Squares (PLS) analysis includes analysis of the outer model and inner model in the form of convergent validity, discriminant validity, composite reliability, determinant coefficient (R2), hypothesis testing.

\section{Convergent Validitys}

Measuring the magnitude of the correlation between the construct and the latent variable can be measured from the loading factor value. The loading factor value for reflective indicators is said to be valid if the loading value $(\lambda)=0.5$.

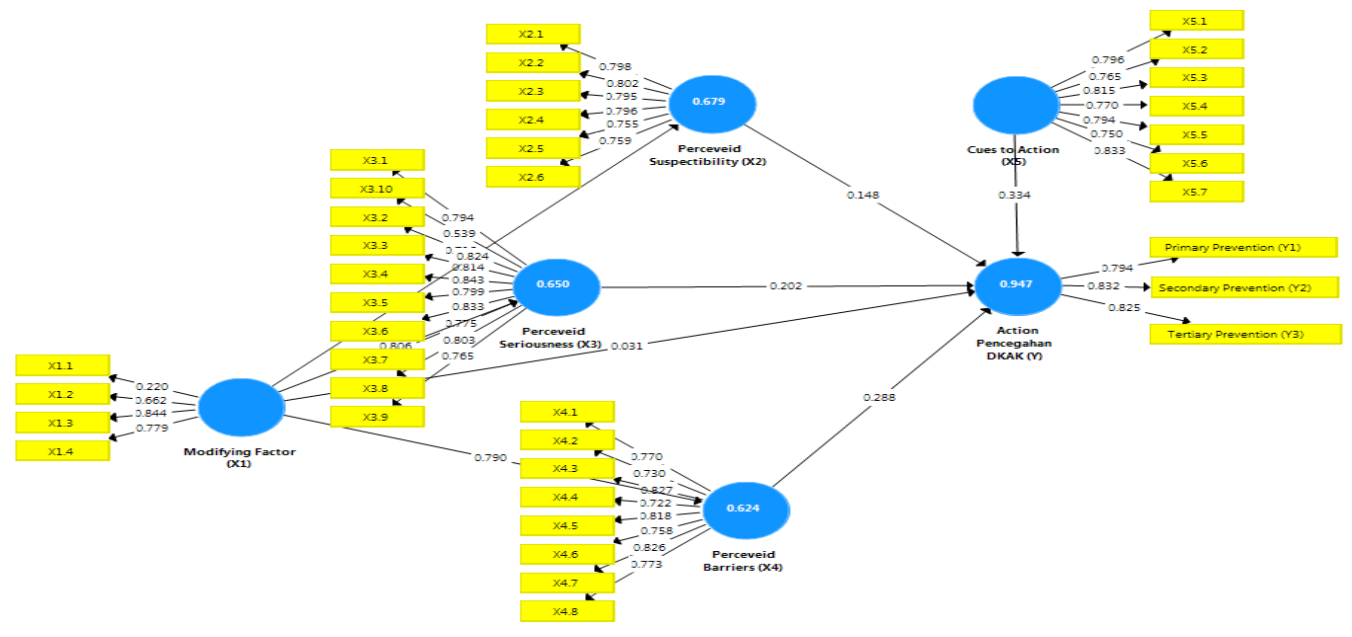

Figure 3. First PLS Model

Based on Figure, it can be seen that the majority of indicators for each variable in this study have a loading value greater than 0.70 , except for indicators X1.1, X1.2, X3.10 which have a value below the loading factor, namely 0.539 . For variable indicators that have a loading value greater than 0.70 , it means that they have a high level of validity, so that they meet the convergent validity and a lower value is eliminated from the model.

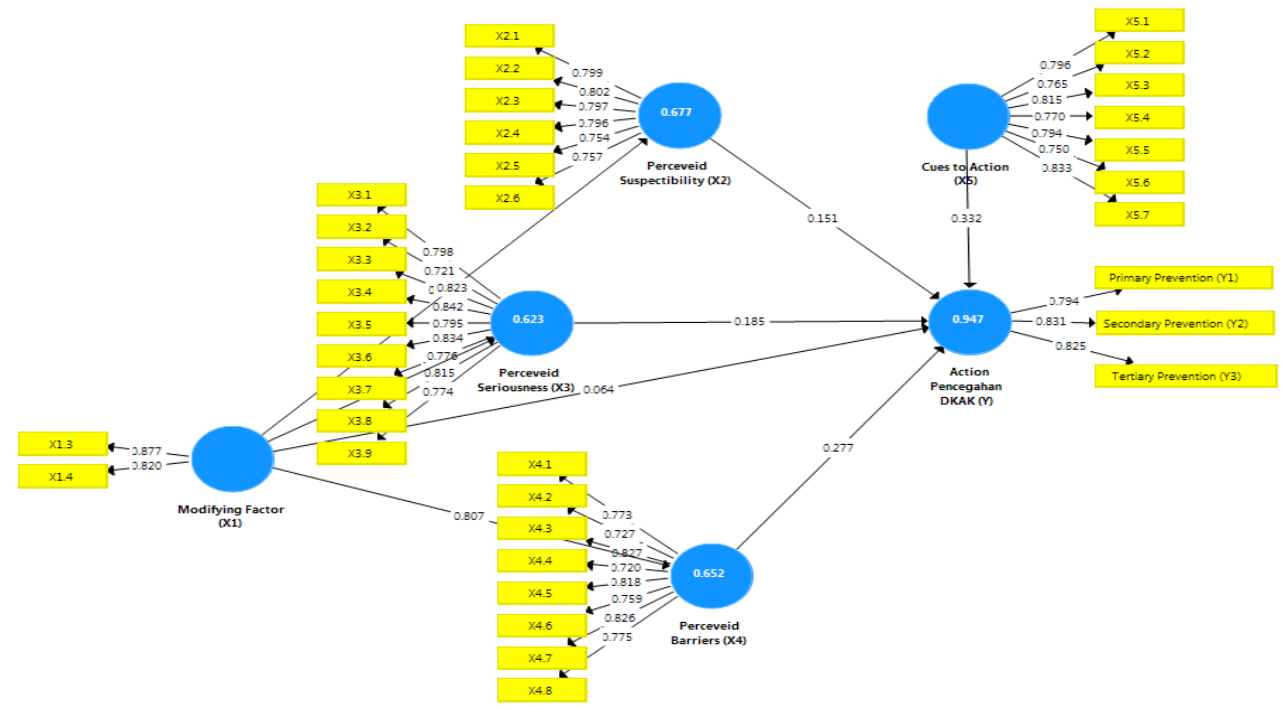

Figure 4. Second PLS Model 


\section{Average Variance Extracted Test}

To evaluate the discriminant validity, it can be seen by the average variance extracted (AVE) method for each construct or latent variable. The model has better discriminant validity if the square root of AVE for each construct is greater than the correlation between the two constructs in the model.

Tabel 1. Average Variance Extracted (AVE) Value Before Modification

\begin{tabular}{|l|c|}
\hline & AVE \\
\hline Modifying Factor (X1) & 0.778 \\
\hline Perceveid suspectibility (X2) & 0.615 \\
\hline Perceveid Seriousness (X3) & 0.636 \\
\hline Perceveid Barriers (X4) & 0.607 \\
\hline Cues to action (X5) & 0.594 \\
\hline Prevention DKAK (Y) & 0.668 \\
\hline
\end{tabular}

From Table 1, it is known that the AVE value of each construct is not below 0.5. Therefore, there is no convergent validity problem in the model being tested so that the construct in this research model has good discriminant validity. and there is no need to modify it again.

\section{Composite Reability}

Composite reliability is used to measure the consistency of the construct. Latent variable is said to be reliable if the composite reliability value is greater than 0.7 . The results of the composite reliability output can be seen in table 2 below.

Tabel 2. Composite Reability

\begin{tabular}{|l|c|}
\hline & Reliabilitas Composite \\
\hline Modifying Factor (X1) & 0.915 \\
\hline Perceveid suspectibility (X2) & 0.838 \\
\hline Perceveid Seriousness (X3) & 0.858 \\
\hline Perceveid Barriers (X4) & 0.921 \\
\hline Cues to action (X5) & 0.940 \\
\hline Prevention DKAK (Y) & 0.906 \\
\hline
\end{tabular}

From Table, it is known that the AVE value of each construct is not below 0.5. Therefore, there is no convergent validity problem in the model being tested so that the construct in this research model has good discriminant validity. and there is no need to modify it again.

\section{Coefficient of Determination (R2)}

The value of R2 is used to measure the degree of variation in the change in the independent variable on the dependent variable or endogenous variables on the exogenous variable. The higher the R2 (R Square) value, the better the prediction model from the model. The results of the output value R2 (R Square) can be seen at.

Table 3. Value of R Square

\begin{tabular}{|l|c|}
\hline & R Square \\
\hline Perceveid suspectibility (X2) & \\
\hline
\end{tabular}




\begin{tabular}{|l|c|}
\hline Perceveid Seriousness (X3) & \\
\hline Perceveid Barriers (X4) & \\
\hline Cues to action (X5) & 0.939 \\
\hline Pencegahan DKAK (Y) & \\
\hline
\end{tabular}

Table 3 shows that the prevention of occupational contact dermatitis is influenced by perceptions of vulnerability, perceived seriousness, perceived resistance, and motivation as much as $93.9 \%$ and the remaining $6.1 \%$ is influenced by other factors not found in the model.

\section{Bootstrapping}

In Smart PLS, testing the effect of each variable is done by using a simulation with the bootstrapping method on the sample. The test results with the bootstrapping method from the Smart PLS analysis are as follows.

Table 5. Bootstrapping Test Results

\begin{tabular}{|l|c|c|c|c|c|}
\hline & $\begin{array}{c}\text { Original } \\
\text { Sample } \\
(\mathbf{O})\end{array}$ & $\begin{array}{c}\text { Sample } \\
\text { Mean (M) }\end{array}$ & $\begin{array}{c}\text { Standard } \\
\text { Deviation } \\
\text { (STDEV) }\end{array}$ & $\begin{array}{c}\text { T statistics } \\
(\mathbf{O} / \mathbf{S T D E V})\end{array}$ & $\begin{array}{c}\text { P } \\
\text { Values }\end{array}$ \\
\hline $\begin{array}{l}\text { Modifying Factor -> } \\
\text { Perceveid Suspectibility }\end{array}$ & 0.823 & 0.825 & 0.029 & 28.638 & 0.000 \\
\hline $\begin{array}{l}\text { Modifying Factor >> } \\
\text { Perceveid Seriousness }\end{array}$ & 0.789 & 0.792 & 0.034 & 23.495 & 0.000 \\
\hline $\begin{array}{l}\text { Modifying Factor -> } \\
\text { Perceveid Barriers }\end{array}$ & 0.802 & 0.806 & 0.029 & 27.271 & 0.000 \\
\hline $\begin{array}{l}\text { Perceveid Suspectibility - } \\
\text { Prevention DKAK }\end{array}$ & 0.213 & 0.205 & 0.139 & 1.533 & 0.126 \\
\hline $\begin{array}{l}\text { Perceveid Seriousness -> } \\
\text { Pencegahan DKAK }\end{array}$ & 0.236 & 0.244 & 0.108 & 2.195 & 0.029 \\
\hline $\begin{array}{l}\text { Perceveid Barriers -> } \\
\text { Preventin DKAK }\end{array}$ & 0.275 & 0.263 & 0.114 & 2.412 & 0.016 \\
\hline $\begin{array}{l}\text { Cues to Action -> } \\
\text { Prevention DKAK }\end{array}$ & 0.223 & 0.235 & 0.097 & 2.293 & 0.022 \\
\hline
\end{tabular}

Table 5 shows the results of the Smart PLS calculation which states the direct effect between variables. It is said that there is a direct effect if the p-value is $<0.05$ and it is said that there is no relationship if the p-value is $>0.05$. Then it can be concluded that the modifying factor variable was significant relationship with the perception of vulnerability, perceived seriousness, and perceived vulnerability, which has a significant relationship with p-value $0.000<0.05$. The variable of susceptibility perception was not significantly related to occupational contact dermatitis prevention variables with $\mathrm{p}$-values $0.126<0.05$. The variable of seriousness perception was significant relationship with the variable of occupational contact dermatitis prevention with p-values $0.029<0.05$. The variable perception of inhibition was significantly related to the variable occupational contact dermatitis prevention with $p$-values $0.016<0.05$. The drive variable was significantly related to the occupational contact dermatitis prevention variable with a $p$-value of $0.022<0.05$. 


\section{Findings of a Model for the Prevention of Occupational Contact Dermatitis}

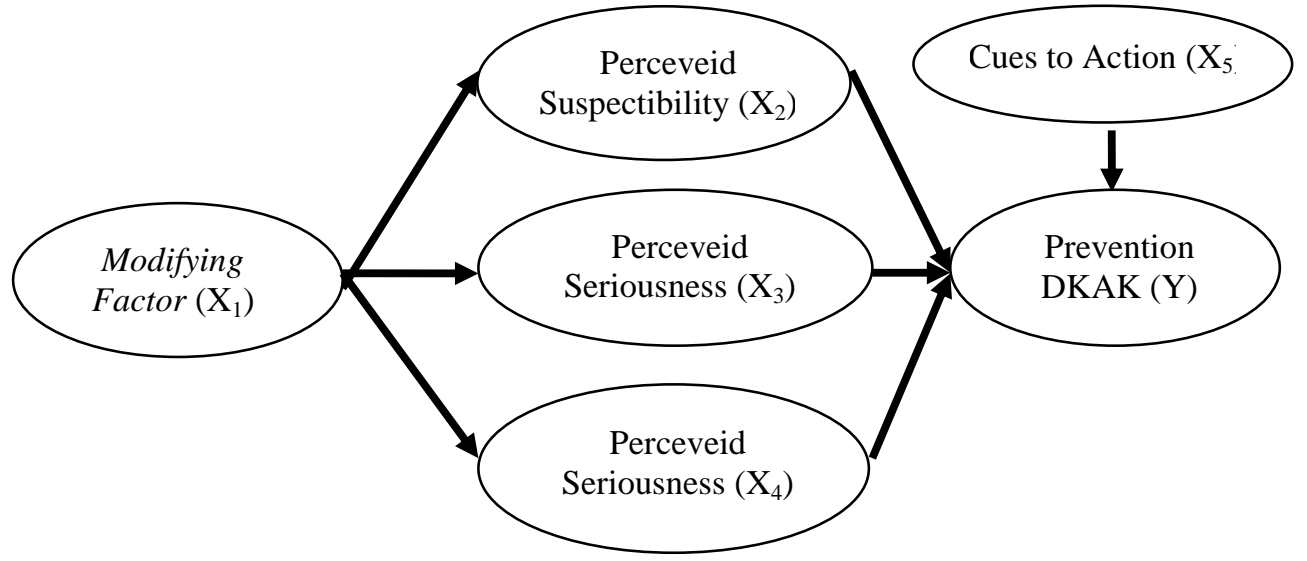

Figure 5. Model Findings

Modifying factors (age, gender, history of contact dermatitis, and knowledge) significantly affect the perceptions of beauty salon employees, except for indicators of age and sex which have no effect on perceptions in preventing occupational contact dermatitis among beauty salon employees in Kendari City. This can be seen from the outer loading value which is smaller than 0.70 , namely 0.220 and 0.662 . According to Edberg (2013) in the HBM theory, age and sex are one of the supporting factors to strengthen the main factors of the HBM theory, this shows that actually age, which is a modifying factor, is not the main factor shaping behavior.

Percevied suspectibility have no effect on preventive measures for occupational contact dermatitis for beauty salon employees in Kendari City. This is based on the findings that most respondents think they are susceptible to occupational contact dermatitis but do not take good preventive measures. According to the respondent, it would be very troublesome if you have to do the job according to the procedure because it takes a long time, the inconvenience of using gloves, it takes a lot of money to carry out health control. This is not in line with Onoruoiza et al (2015) which states that perceived vulnerability actually refers to a subjective assessment of risks to health problems. A person who admits that they have a low risk of disease is more likely to commit unhealthy behavior. Meanwhile, someone who views them as having a high risk will be more likely to perform behaviors that reduce their risk of developing disease.

Percevied Seriousness have a significant effect to preventive measures of occupational contact dermatitis for beauty salon employees in Kendari City. This is based on the findings that most of the respondents who thought this disease was serious and had an impact on the work processes of salon employees would take good preventive measures. Perceptions of vulnerability affect the preventive measures of occupational contact dermatitis for beauty salon employees in Kendari City. This is based on the findings that most of the respondents who thought this disease was serious and had an impact on the work processes of salon employees would take good preventive measures

Percevied barriers have a significant effect to preventive action of occupational contact dermatitis for beauty salon employees in Kendari City. This is based on the finding that respondents with low barriers tend to prevent occupational contact dermatitis. In the HBM theory it is explained that everything that hinders this can be seen in terms of expensive, timeconsuming, inconvenient, unsatisfactory and pleasant health services, This is also supported by 
the results of Ansela's (2020) research which reveals that there is an influence between the perception of barriers to preventing a disease. Perceptions of barriers felt by beauty salon employees in this study stated that there were barriers to lack of information about occupational diseases, high prices for materials with good quality, it would cost a lot if you had to carry out health control.

Cues to action has a significant effect to preventive measures of occupational contact dermatitis for beauty salon employees in Kendari City. This is based on the findings that the majority of beauty salon employee respondents who have a big motivation tend to make good prevention efforts, which come from support, knowledge from the mass media, the dangers of work-induced contact dermatitis 5 . As for the encouragement felt by beauty salon employees in This research is for example messages in the mass media, advice or suggestions from coworkers, worry from the family if they experience work-related diseases, knowledge, the workplace environment such as the existence of several beauty salons that require workers to have a job training certificate when they want to apply for workers salon, and there is a sense of security when using gloves (PPE) at work.

The findings in this study regarding the occupational contact dermatitis prevention model show that the majority of respondents practice prevention of dermatitis only at the second (secondary prevention) and third (tertiary prevention) levels, and only a small proportion of them practice the first level of prevention (primary prevention). This is due to the lack of information and knowledge as well as economic problems and the inconvenience of using PPE on beauty salon employees in Kendari City. For beauty salon employees who do prevention, think that this is a need of them because they feel safe and comfortable when using PPE. There are also some respondents who work in beauty salons who require their employees to have a job training certificate.

\section{Conclusion}

Based on the results of the study, it can be concluded that modifying factors have a significant effect on the prevention of occupational contact dermatitis except for indicators of age and gender, perceptions of seriousness, resistance, motivation have a significant effect on the prevention of occupational contact dermatitis and perceptions of vulnerability have no significant effect against the prevention of occupational contact dermatitis.

\section{References}

Audina, D. V., Budiastuti, A., \& Widodo, Y. A. (2017). Faktor penyebab terjadinya dermatitis kontak akibat kerja pada pekerja salon. Diponegoro Medical Journal (Jurnal Kedokteran Diponegoro) , 6, 1-11.

Ansela, Y., Sugiarto, S., \& Wuni, C. (2020). Faktor-Faktor Yang Berhubungan Dengan Upaya Pencegahan Dermatitis Kontak Iritan Pada Pekerja Cucian Motor. Journal of Healthcare Technology and Medicine, 6(1), 459-467.

BPS. (2019). Kota Kendari Dalam Angka 2019. Badan Pusat Statistik. Available from: https://kendarikota.bps.go.id/publication/2019/08/16/6bf1f9ba2813e6a4eb69fdfd/kotakendari-dalam-angka-2019.html

Edberg, M. (2013). Essentials of Health Behavior. Jones \& Bartlett Publishers. 
Eeckelaert, L., Dontas, S., Georgiadou, E., \& Koukoulaki, T. (2014). Occupational health and safety in the hairdressing sector. Luxembourg, Luxembourg: European Agency for Safety and Health at Work, 1-30.

International Labour Organization. (2018). World Emploment Social Outlook: Trends 2018. Geneva: International Labour Office.

Jason. (2017). Tingkat Pengetahuan Pekerja Salon Terhadap Dermatitis Kontak Di Kecamatan Medan Petisah Kota Medan Pada Tahun 2016. Jurnal Kedokteran Universitas Sumatera Utara, Volume, 40(2), 1-12.

Kuhn, S., Milasi, S., \& Yoon, S. (2018). World employment social outlook: Trends 2018. Geneva: ILO.

Ma, G. X., Wei, Z., Husni, R., Do, P., Zhou, K., Rhee, J., ... \& Yeh, M. C. (2019). Characterizing occupational health risks and chemical exposures among Asian nail salon workers on the East Coast of the United States. Journal of community health, 44(6), 1168-1179.

Onoruoiza, S. I., Musa, A., Umar, B. D., \& Kunle, Y. S. (2015). Using health beliefs model as an intervention to non compliance with hypertension information among hypertensive patient. Int Organ Sci Res J Human Soc Sci, 20(9), 11-16.

Suma'mur, P. K. (2014). Higiene Perusahaan dan Kesehatan Kerja (Hiperkes) Edisi 2. Jakarta: Sagung Seto. 